Алексеенко А.А., Колесников А.Н.

Государственная образовательная организация высшего профессионального образования «Донецкий национальный медицинский университет имени М. Горького»

\title{
КРИКОТИРЕОИДНАЯ АНЕСТЕЗИЯ ПРИ ЭКСТРЕМАЛЬНЫХ СИТУАЦИЯХ
}

\section{АКТУАЛЬНОСТЬ}

Внедрение мультимодальной анестезии без опиоидов в схему проведения анестезии в хирургической стоматологии, имплантологии эффективно отразилось на обезболивании пациента. Однако этого недостаточно для проведения интубации трахеи. Существуют различные методы местной анестезии, способствующие угнетению болевых ощущений для установки эндотрахеальной трубки [Xue FS, Asai T]. Эффективно использование спрея с лидокаином; при этом его постепенно продвигают в дыхательные пути [Nath P]. Все чаще врачи-анестезиологи начали сталкиваться с проблемой отсутствия как деполяризующих, так и недеполяризующих миорелаксантов, особенно в амбулаторных условиях и при проведении интубации трахеи во время экстремальных ситуаций. Данная проблема наталкивает на использование альтернативных методов достижения арефлексии при интубации трахеи.

\section{ЦЕЛЬ РАБОТЫ}

Внедрить метод атравматичной, безопиоидной анестезии при интубации трахеи при экстремальных ситуациях, используя методику крикотиреоидной анестезии.

Материал и методы

Внедрение методики проводилось в «студии имплантологии доктора Дзюбы» г. Донецк и стоматологии «Экселенс» г. Ростов-на-Дону.

Анестезиологическое обеспечение 126 пациентов (54 мужчин и 72 женщины) проводилось при различных видах оперативного стоматологического лечения методом проведения общей ингаляционной (севофлюран) в комбинации с местной инфильтрационной и проводниковой (комбинированной) анестезии с вспомогательной искусственной вентиляцией легких в режиме вентиляции Pressure support ventilation и протекцией дыхательных путей с помощью назотрахеальной интубации.

\section{РЕЗУЛЬТАТЫ ИССЛЕДОВАНИЯ}

В премедикацию назначали внутривенное введение атропина 0,1\% - 0,01-0,02 мг/кг, дексаметазона в дозе 0,2 мг/кг, лидокаина 1,5 мг / кг (максимально 100 мг). Доза болюса составляла раствора MgSO4 25\% - 10 мл внутривенно капельно на растворе глюкозы 5\% - 200 мл. Обезболивание при проведении общей анестезии выполнялось местной и проводниковой анестезией раствором убистезина 4\% с эпинефрином 1:100 000 в полном объеме. После индукции в анестезию пропофолом в дозе 2 - 2,5 мг/кг проводилась крикотиреоидная анестезия. Пациент находится лежа на спине, шея в нейтральной позиции.

Техника крикотиреоидной анестезии:

1. После обработки антисептическим раствором, отграничивается кожа передней поверхности шеи стерильными салфетками.

2. Определяется крикотиреоидная связка ниже щитовидного хряща по средней линии шеи.

3. Производится местная инфильтрационная анестезия лидокаином $2 \%$ кожи в области перстневидно-щитовидной связки.

4. Пунктируется внутримышечной иголкой, установленной на шприц ёмкостью 5 мл, перстневидно-щитовидная связка по средней линии, направляя иглу под углом $45^{\circ}$ к поверхности кожи.

5. Осторожно продвигается игла, подтягивая к себе поршень шприца. Когда начнет аспирироваться воздух, продвижение прекращается, что подтверждает положение иглы в просвете трахеи.

6. После идентификации иглы в трахеи болюсно вводится 4 мл раствора лидокаина $2 \%$

7. Введение лидокаина вызывает кашель, так как анестетик раздражает трахею, и приводит к местному обезболиванию орошением голосовых связок и надгортанной области при распространении 
анестетика.

\section{ЗАКЛЮЧЕНИЕ}

Применение крикотиреоидной анестезии дало ряд преимуществ:

1. Возможность отказа от применения миорелаксантов всех групп.

2. Возможность применения при прогнозируемой трудной интубацией трахеи.

3. Улучшение обзора (открытие голосовой щели) при интубации трахеи.

4. Отсутствие рефлекторных реакций на введение эндотрахеальной трубки.

5. Уменьшение индукционной дозы пропофола на $12,45 \pm 2,37 \%$.

6. Снижение жалоб на кашель, боль при глотании после экстубации.

Сведения об авторах

Алексеенко А.А., врач-анестезиолог высшей категории, ассистент кафедры анестезиологии, реаниматологии и неонатологии ГОО ВПО ДОННМУ ИМ.М. гОРЬКОГО,, тел. +380713579959, e-mail alexeyenko3@ukr.net

Колесников А.Н., д.мед.н., профессор, зав. кафедрой анестезиологии, реаниматологии и неонатологии ГОО ВПО ДОННМУ ИМ.M. ГОРЬКОГО, +380713134370, e-mail akolesnikov1972@gmail.com 